\title{
ANTIOXIDANT ACTIVITY OF BIOACTIVE PEPTIDE DERIVED FROM PEKIN DUCK FEET GELATIN HYDROLYSATE
}

\author{
FATIN ARINA MOHD ZAIN ${ }^{1}$, NORSHAZILA SHAHIDAN ${ }^{1 *}$, NURUL HUDA ${ }^{2}$, \\ ZARINAH ZAKARIA ${ }^{1}$ and ABDI WIRA SEPTAMA ${ }^{3}$ \\ ${ }^{1}$ Faculty of Bioresources and Food Industry, Universiti Sultan Zainal Abidin, Terengganu, Malaysia \\ ${ }^{2}$ Faculty of Food Science and Nutrition, Universiti Malaysia Sabah, Sabah, Malaysia \\ ${ }^{3}$ Research Centre for Chemistry, Indonesian Institute of Science, Jakarta, Indonesia \\ ${ }^{*}$ E-mail: norshazila@unisza.edu.my
}

Accepted 2 October 2020, Published online 25 December 2020

\begin{abstract}
Malaysia is one of the main producers of duck meat globally with increasing demands. Increasing in duck production will also increase the number of duck by-products such as skin, feet and bones. Pekin duck (Anas platyrhyncos domestica) is one of the famous duck breeds. Gelatin that was extracted from Pekin duck feet has shown a potential raw material for the production of bioactive peptide that can involve in various functions of the organism physiologically for example antioxidant effects. Pekin Duck feet gelatin was hydrolyzed by using five commercial enzymes (Alcalase, Esperase, Flavourzyme, Neutrase and Protamex) to identify radical scavenging potencies of derived bioactive peptides. All the five enzymes were studied under three different enzyme-substrate ratio $(1: 10,1: 15,1: 20)$ with every enzyme optimum $\mathrm{pH}$ and temperature. Scavenging activities studied included DPPH radical scavenging activity and ABTS radical scavenging activity. In DPPH radical scavenging activity, all the five enzymes showed the highest percentage of radical scavenging activity at (1:20) enzyme-substrate ratio condition. Among the five enzymes studied, gelatin hydrolyzed with Protamex showed the highest activity (54.83\%), followed by Alcalase (53.12\%), Esperase (49.81\%), Flavourzyme (49.32\%) and lastly Neutrase $(47.49 \%)$ at sample concentration 4.5 $\mathrm{mg} / \mathrm{ml}$. The half-maximal inhibitory concentration $\left(\mathrm{IC}_{50}\right)$ value of the bioactive peptide for ABTS radical scavenging activity was measured. Alcalase has produced the duck feet gelatin hydrolysate that has the lowest $\mathrm{IC}_{50}$ value against ABTS radical scavenging activity with value $(0.45 \%)$ followed by Esperase $(0.54 \%)$, Neutrase $(0.57 \%)$, Protamex $(0.60 \%)$ and lastly Flavourzyme $(0.74 \%)$
\end{abstract}

Key words: Gelatin hydrolysate, duck feet, enzymatic hydrolysis, antioxidant, bioactive peptide scavenging activity

\section{INTRODUCTION}

Peptides have the same ability to produce antioxidant activity like other antioxidants with the replicate mechanism (Jemil et al., 2016). Antioxidant peptides can be used to manage lipid and protein oxidation that causes oxidative stress in the human body by being endorsed as food ingredients, enhance in the functional food and nutraceuticals (Liu et al., 2016). Hence it can help to enhance public health as well as reducing economic losses in food production (Lorenzo et al., 2018).

The type of proteases play a vital role for the composition, amount, amino acid sequence, size, and also influence the antioxidant activity of hydrolysate

\footnotetext{
* To whom correspondence should be addressed.
}

(Liu et al., 2016). Alcalase, Flavourzyme and Protamex are industrial food-grade proteinases that have been used in the generation of antioxidant peptides in duck breast meat (Wang et al., 2015). The use of Esperase is usually rare, although Mosquera et al. (2015) reported the use of this enzyme on dried giant squid tunic gelatin hydrolysate to produce bioactive peptide. Lastly, the usage of Neutrase enzyme is due to the study of blood clam muscle hydrolysate (Tegillarca granosa) that has high antioxidant activity (Chi et al., 2015). Food protein that was hydrolyzed with different peptidases will produce various peptides pattern (Toldra et al., 2017).

Kim et al. (2016) reported that the reason for choosing duck feet as a raw material for collagen and gelatin production is due to its complex part of bones and tendons. There are several studies about 
extraction of gelatin from Pekin duck feet by using the acidic, alkaline and enzymatic treatment. All the extraction process has produced duck feet gelatin with a distinguished amount of yield for example acetic acid (4\%), sodium hydroxide (3\%) and Pepsin (5\%) (Abedinia et al., 2017; Nik Muhammad et al., 2017). The previous study from Kuan et al. (2017) focuses on physicochemical properties of duck feet gelatin and less on peptide bioactive compound. Nevertheless, there is little information about antioxidant peptides from duck feet gelatin. Therefore, the main objectives of this study were to investigate the scavenging activities (DPPH and ABTS) of duck feet gelatin hydrolysate prepared with five different types of enzyme (Alcalase, Esperase, Flavourzyme, Neutrase and Promex) with three different enzyme-substrate ratio treatment (1:20, 1:15 and 1:10).

\section{MATERIALS AND METHODS}

\section{Materials}

The Pekin duck feet was purchased from Perak Duck Food Industries Sdn Bhd, Khaki Campbell duck feet was purchased from 4R Agro Enterprise, Pasir Mas, Kelantan and Muscovy duck feet was purchased from duck farm at Kota Bharu, Kelantan. The raw materials were transported under the refrigerated condition to Muscle Lab, Faculty Bioresources and Food Industry, University Sultan Zainal Abidin and stored at $-18^{\circ} \mathrm{C}$ before use. Commercial proteases (Alcalase, Esperase, Flavourzyme, Neutrase and Protamex), DPPH, ABTS and Trolox were purchased from Sigma-Aldrich (St. Louis, United State).

\section{Preparation of duck feet gelatin hydrolysates}

Gelatin from Pekin duck feet was extracted by using the method described by Kuan et al. (2017). Duck feet gelatin was hydrolyzed by using five different commercial enzymes which are Alcalase, Esperase, Flavourzyme, Protamex and Neutrase. The sample was hydrolyzed for $6 \mathrm{hr}$ under every enzyme optimal temperature and $\mathrm{pH}$ conditions with an enzyme-substrate ratio of $1: 10$, $1: 15$ and $1: 20(\mathrm{w}: \mathrm{w})$ according to the method of Jin et al. (2016). The optimum condition for Alcalase and Flavourzyme is at $\mathrm{pH} 7$ at temperature $50^{\circ} \mathrm{C}$ and Neutrase at $\mathrm{pH} 6$ and temperature $50^{\circ} \mathrm{C}$. Meanwhile, optimum condition for Protamex is at $\mathrm{pH} 7$ and temperature $60^{\circ} \mathrm{C}$ and for Esperase the optimum condition is at $\mathrm{pH} 8$ and temperature $60^{\circ} \mathrm{C}$ (Hwang et al., 2010; Lee et al., 2012). The $\mathrm{pH}$ of the reaction was kept constant by adding a $1 \mathrm{~N} \mathrm{NaOH}$ and $1 \mathrm{~N} \mathrm{HCl}$ solution to the reaction. The enzymes were inactivated by heating at $100^{\circ} \mathrm{C}$ for $10 \mathrm{~min}$, and the samples were centrifuge (Sigma Sartorius, Germany) at $3000 \mathrm{~g}$ for $20 \mathrm{~min}$. The supernatants which comprise the hydrolysates was lyophilized (Freeze dryer Christ alpha 1-4 LD plus) and stored at $-80^{\circ} \mathrm{C}$ for further assays.

\section{DPPH scavenging activity}

The DPPH radical scavenging activity of CSGH was determined using the method described by Razali et al. (2015) with some modifications. About $500 \mu \mathrm{L}(4.5 \mathrm{mg} / \mathrm{mL})$ of sample solution was mixed with $500 \mu \mathrm{L}$ of ethanol and $125 \mu \mathrm{L} 0.02 \%$ $(\mathrm{w} / \mathrm{v})$ of DPPH in $99.5 \%$ ethanol. Then, the mixture was shaken vigorously and incubated in a dark place. After $60 \mathrm{~min}$, the absorbance was measured at $517 \mathrm{~nm}$ using a spectrophotometer (ThermoSpectronic Genesys 20). 6-hydroxy-2,5,7,8tetramethylchroman-2-carboxylic acid (Trolox) acts as a positive control. All determinations were based on the means of three measurements. The calculation of the DPPH radical scavenging activity was calculated as follows:

Radical Scavenging activity $(\%)=$

$\left[\left(A_{\text {blank }}-A_{\text {sample }}\right) / A_{\text {blank }}\right] \times 100$

where $A_{\text {blank }}=$ absorbance of the control (blank) and $A_{\text {sample }}=$ absorbance of the sample.

\section{ABTS scavenging activity}

ABTS radical [2,22 -azino-bis-(3ethylbenzothiazoline-6-sulfonic acid)] scavenging assay was carried out according to the method described by Chi et al. (2015). The stock solution of ABTS radical consisted of $7 \mathrm{mM}$ ABTS in potassium persulfate $2.45 \mathrm{mM}$, kept in the dark at room temperature for $16 \mathrm{hr}$. An aliquot of stock solution was diluted with methanol to give the working solution of ABTS radical an absorbance at $734 \mathrm{~nm}$ of $0.70 \pm 0.02$. A $20 \mu \mathrm{L}$ aliquot sample was mixed with $200 \mu \mathrm{L}$ of ABTS reagent and then left to stand in the dark at $30^{\circ} \mathrm{C}$ for $10 \mathrm{~min}$. A spectrophotometric assay was carried out in a 96well plate and absorbance values were read at 734 $\mathrm{nm}$ using a microplate reader (Multiskan Go Thermo Scientific). The ABTS scavenging activities of the samples were calculated using the following equation:

ABTS scavenging activity $(\%)=$ [ $\left.\left(A_{\text {control }}-A_{\text {sample }}\right) / A_{\text {control }}\right] \times 100$

where $A_{\text {control }}=$ absorbance without sample, $A_{\text {sample }}$ $=$ absorbance with sample. 


\section{RESULT AND DISCUSSION}

\section{DPPH scavenging activity}

DPPH method is the convenient method to estimate the capability of antioxidants to scavenge free radicals because it is a stable free radical that exhibit maximum absorbance at $517 \mathrm{~nm}$ (Christodouleas et al., 2014; Wang et al., 2015). Free radicals will be scavenged by antioxidants through hydrogen atom donation and the absorbance will be reduced (Wang et al., 2015; Nenadis \& Tsimidou, 2018). Figure 1 below presents the DPPH scavenging activity for five enzymes (Alcalase, Esperase, Flavourzyme, Neutrase and Protamex) under three different enzyme-substrate ratios $(1: 20,1: 15,1: 10)$ at concentration sample $4.5 \mathrm{mg} / \mathrm{mL}$ respectively.

The highest DPPH scavenging activity for Alcalase is at enzyme-substrate ratio 1:20 (53.12\%), followed by enzyme-substrate ratio 1:10 (33.05\%) and enzyme-substrate ratio 1:15 (15.97\%) accordingly. The scavenging ability obtained in this study was higher than the study reported by Hasyera and Omar (2016) using chicken skin gelatin hydrolysate which had scavenging activity of $47.33 \%$ under treatment enzyme-substrate ratio 1:20. Duck feet gelatin hydrolysate has a higher scavenging activity compare to chicken skin gelatin hydrolysate because duck feet consist of complex parts of tendons and bones hence it can produce more bioactive peptide.

DPPH scavenging activity of duck feet gelatin hydrolysates examined possessed antioxidant activity which was independent on the hydrolysis treatment employed. The hydrolysate yield from Protamex enzyme drop from 1:20 (54.83\%) to $1: 10$
(15.13\%) and finally 1:15 (13.05\%). Wang et al. (2015) reported that the duck meat hydrolysate that was hydrolyzed using Protamex enzyme has $82.09 \%$ DPPH radical scavenging activity at a lower concentration sample $(1 \mathrm{mg} / \mathrm{mL})$ which are higher than DPPH radical scavenging activity of duck feet gelatin hydrolysate.

All the five enzymes (Alcalase, Esperase, Flavourzyme, Neutrase and Protamex) that were used to produce duck feet gelatin hydrolysate showed the highest DPPH scavenging activity at enzyme-substrate ratio (1:20). The radical scavenging activities for Alcalase, Esperase, Flavourzyme, Neutrase and Protamex are 53.12\%, $49.81 \%, 49.32 \%, 47.49 \%$ and $54.83 \%$ accordingly. The most suitable enzymes that can be used to produce duck feet gelatin hydrolysate with optimum DPPH scavenging activity are Protamex and Alcalase. Alcalase is an endopeptidase which has broad specificity and preference for uncharged residues for example Ser, Thr, Asp and Glu (Lunavital et al., 2014). Meanwhile, Protamex is a mixture of endopeptidase and exopeptidase that work faster in peptide chain compared to Alcalase (Piotrowicz \& Mellado, 2015). This study was supported by Latorres et al. (2017) finding where white shrimp (Litopenaeus vannamei) protein hydrolysate hydrolyzed with Protamex has a higher radical scavenging activity than protein hydrolysate hydrolyzed with Alcalase. The difference in the radical scavenging activity is caused by the amino acid composition, hydrophobicity, length and sequence of peptides within protein hydrolysates (Salem et al., 2017).

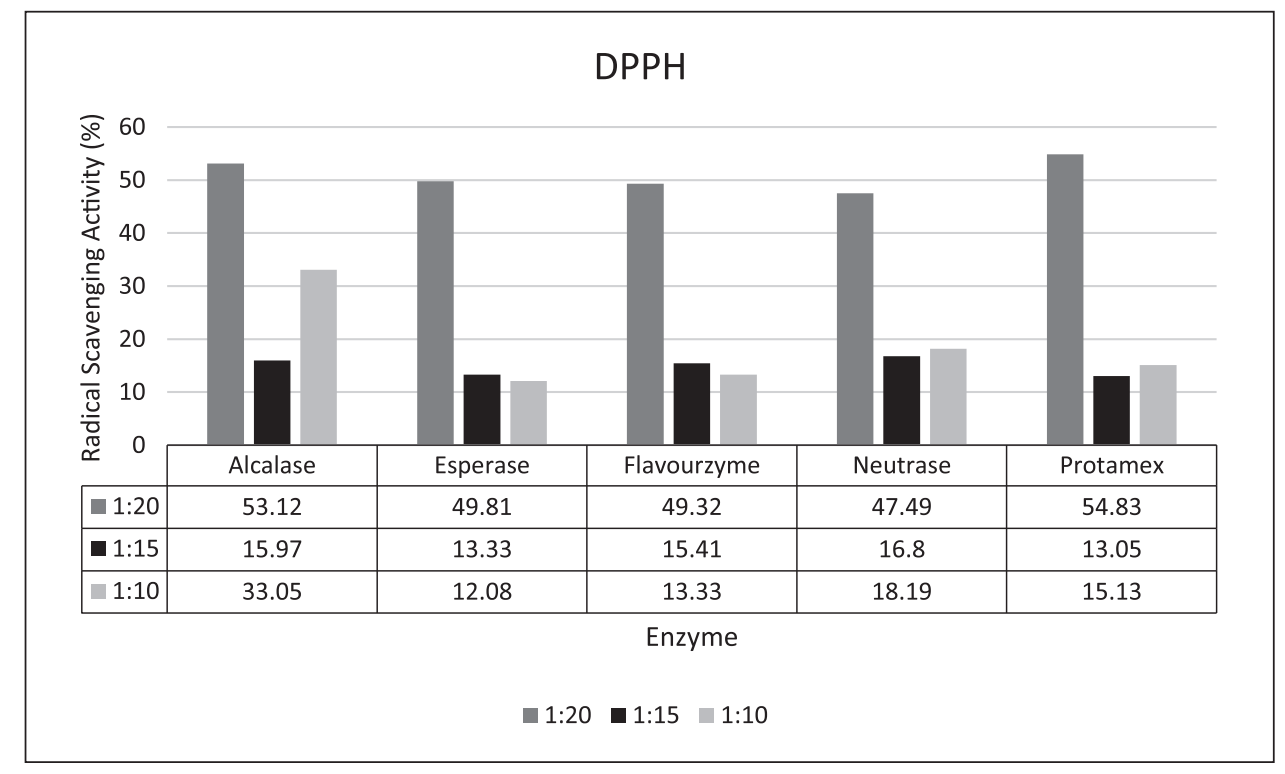

Fig. 1. DPPH scavenging activity for five enzyme (Alcalase, Esperase, Flavourzyme, Neutrase and Protamex) with three different enzyme-substrate ratio $(1: 20,1: 15,1: 10)$ at concentration sample $4.5 \mathrm{mg} / \mathrm{mL}$. 
Table 1. ABTS scavenging activity for five enzymes (Alcalase, Esperase, Flavourzyme, Neutrase and Protamex) with three different enzyme-substrate ratios $(1: 20,1: 15,1: 10)$ at concentration sample $4.5 \mathrm{mg} / \mathrm{mL}$

\begin{tabular}{cccc}
\hline Enzyme - Substrate Ratio & $1: 20(\%)$ & $1: 15(\%)$ & $1: 10(\%)$ \\
\hline Alcalase & $0.45 \pm 0.02^{\mathrm{a}}$ & $0.58 \pm 0.01^{\mathrm{b}}$ & $0.47 \pm 0.01^{\mathrm{a}}$ \\
Esperase & $0.54 \pm 0.02^{\mathrm{a}}$ & $0.60 \pm 0.01^{\mathrm{b}}$ & $0.61 \pm 0.02^{\mathrm{b}}$ \\
Flavourzyme & $0.76 \pm 0.01^{\mathrm{a}}$ & $0.74 \pm 0.01^{\mathrm{a}}$ & $0.81 \pm 0.03^{\mathrm{b}}$ \\
Neutrase & $0.70 \pm 0.02^{\mathrm{c}}$ & $0.57 \pm 0.01^{\mathrm{a}}$ & $0.61 \pm 0.01^{\mathrm{b}}$ \\
Protamex & $0.75 \pm 0.01^{\mathrm{c}}$ & $0.60 \pm 0.02^{\mathrm{a}}$ & $0.64 \pm 0.01^{\mathrm{b}}$ \\
\hline
\end{tabular}

\section{ABTS scavenging activity}

Antioxidant activity of hydrophilic and lipophilic compounds was measure by ABTS radical capture method (Centenaro et al., 2014). This method involving electron transfer method based on the decrease of ABTS radical solution absorbance within the range 710-760 $\mathrm{nm}$ (Christodouleas et al., 2014). Table 1 below presents the ABTS scavenging activity for five enzymes (Alcalase, Esperase, Flavourzyme, Neutrase and Protamex) under three different enzyme-substrate ratios $(1: 20,1: 15,1: 10)$ at concentration sample $4.5 \mathrm{mg} / \mathrm{mL}$ respectively.

Duck feet gelatin hydrolysate that was obtained from Alcalase enzyme showed the $\mathrm{IC}_{50}$ value for ABTS scavenging activity at concentration sample $4.5 \mathrm{mg} / \mathrm{mL}$. $\mathrm{IC}_{50}$ result for the enzyme-substrate ratio $(1: 20),(1: 15)$ and $(1: 10)$ are $0.45 \%, 0.58 \%$ and $0.47 \%$ respectively. Thus, the enzyme-substrate ratio $(1: 20)$ has the highest scavenging activity compare to other hydrolysates produce with Alcalase enzyme. Mosquera et al. (2015) reported that dried giant squid tunic hydrolysate that was hydrolyzed using Alcalase enzyme has $43.79 \%$ of ABTS radical scavenging activity at concentration sample $45 \mathrm{mg} / \mathrm{g}$. Duck feet gelatin hydrolysate has a higher ABTS radical scavenging activity than dried giant squid tunic that was hydrolyzed by using the same enzyme.

Duck feet gelatin hydrolysate that was obtained from Esperase enzyme showed the $\mathrm{IC}_{50}$ value for ABTS scavenging activity at concentration sample $4.5 \mathrm{mg} / \mathrm{mL}$. The enzyme-substrate ratio $(1: 20)$ has the lowest $\mathrm{IC}_{50}$ value which is $0.54 \%$. Meanwhile, both the enzyme-substrate ratio $(1: 15)$ and $(1: 10)$ had the comparable $\mathrm{IC}_{50}$ value which was $0.60 \%$ and $0.61 \%$ respectively. Mosquera et al. (2015) reported that dried giant squid tunic hydrolysate that was hydrolyzed using Esperase enzyme has $43.36 \%$ of ABTS radical scavenging activity at concentration sample $45 \mathrm{mg} / \mathrm{g}$. Protein hydrolysate of dried giant squid tunic with a higher concentration sample has a lower radical scavenging activity than duck feet gelatin hydrolysate obtained from the Esperase enzyme.
The highest $\mathrm{IC}_{50}$ value for ABTS scavenging activity for duck feet gelatin hydrolysate produced from Alcalase and Esperase is at enzyme-substrate ratio $(1: 20)$ which are $0.45 \%$ and $0.54 \%$ and respectively. Meanwhile Flavourzyme, Neutrase and Protamex generate a bioactive peptide that has the highest $\mathrm{IC}_{50}$ at enzyme-substrate ratio $(1: 15)$ which are $0.74 \%, 0.57 \%$ and $0.60 \%$ accordingly. Hydrolysates reducing activity was affected by the enzyme type since there was a verified significant difference between the values in the same period of reaction (Latorres et al., 2017). Alcalase are more likely to cleave protein at the carboxy side of hydrophobic residues (Toldra et al., 2017). Esperase is a serine-type endoprotease that shown a high proteolytic activity on fish and cephalopod waste substrates (Vazquez et al., 2017). Meanwhile, Flavourzyme and Protamex are mixtures of endopeptidase and exopeptidase that work faster in peptide chain compare to Alcalase (Piotrowicz \& Mellado. 2015). While Neutrase has broad specificity and preferably for N-terminus, Leu and Phe (Toldra et al., 2017).

\section{CONCLUSION}

In conclusion, the type of enzyme and enzymesubstrate ratio of duck feet gelatin hydrolysate play a significant role in antioxidant activity. This activity includes the DPPH radical scavenging activity and ABTS radical scavenging activity. Duck feet gelatin is a potential raw material that can be used to produce bioactive peptide hence reducing the waste product in the environment. Overall, this peptide has the potential to be developed into new biomaterials.

\section{ACKNOWLEDGEMENT}

This work was financially supported by the Universiti Sultan Zainal Abidin, Malaysia through Special Research Grant Scheme (SRGS) UniSZA/ 2017/SRGS/03. 


\section{REFERENCES}

Abedinia, A., Ariffin, F., Huda, N. \& Nafchi, A.M. 2017. Extraction and characterization of gelatin from the feet of Pekin duck (Anas platyrhynchos domestica) as affected by acid, alkaline, and enzyme pretreatment. International Journal of Biological Macromolecules, 98: 586-594.

Centenaro, G.S., Sallas-Mellado, M., Pires, C., Batista, I., Nunes, M. \& Prentice, C. 2014. Fractionation of protein hydrolysates of fish and chicken using membrane ultrafiltration: investigation of antioxidant activity. Application Biochemical Biotechnology, 172: $2877-$ 2893.

Christodouleas, C.D., Fotakis, C., Nikokavoura, A., Papadopoulos, K. \& Calokerinos, A.C. 2014. Modified DPPH and ABTS assays to assess the antioxidant profile of untreated oils. Food Analysis Methods, 8: 1294-1302.

Chi, C.F., Hu, F.Y., Wang, B., Li, T. \& Ding, G.F. 2015. Antioxidant and anticancer peptides from the protein hydrolysate of blood clam (Tegillarca granosa) muscle. Journal of Functional Foods, 15: 301-313.

Hasyera, W. \& Omar, W. 2016. Effect of drying method on functional properties and antioxidant activities of chicken skin gelatin hydrolysate. Journal of Food Science and Technology, 53: 3928-3938.

Hwang, J.Y., Shyu, Y.S., Wang, Y.T. \& Hsu, C.K. 2010. Antioxidative properties of protein hydrolysate from defatted peanut kernels treated with esperase. $L W T-$ Food Science and Technology, 43: 285-290.

Jemil, I., Mora, L., Nasri, R., Abdelhedi, O., Aristoy, M.C., Hajji, M., Nasri, M. \& Toldrá, F. 2016. A peptidomic approach for the identification of antioxidant and ACE-inhibitory peptides in sardinelle protein hydrolysates fermented by Bacillus subtilis A26 and Bacillus amyloliquefaciens An6. Food Research International, 89: 347-358.

Jin, S.K., Choi, J.S., Lee, S.J., Lee, S.Y. \& Hur, S.J. 2016. Antioxidant, liver protective and angiotensin i- converting enzyme inhibitory activities of old laying hen hydrolysate in crab meat analogue. Asian Australas Journal Animal Sciences, 29(12): 1774-1781.

Kim, H.Y., Yeo, I.J., Hwang, K.E., Song, D.H., Kim, Y.J., Ham, Y.K., Jeong, T.J., Choi, Y.S. \& Kim, C.J. 2016. Isolation and characterization of pepsin-soluble collagens from bones, skins and tendons in duck feet. Korean Journal for Food Science Animal, 36(5): 665-670.
Kuan, Y.H., Nafchi, A.M., Huda, N., Ariffin, F. \& Karim, A.A. 2017. Comparison of physicochemical and functional properties of duck feet and bovine gelatins. Journal of the Science of Food and Agriculture, 97(5): 1663-1671.

Latorres, J.M., Rios, D.G., Saggiomo, G., Wasielesky Jr. W., Prentice-Hernandez, C. 2017. Functional and antioxidant properties of protein hydrolysates obtained from white shrimp (Litopenaeus vannamei). Journal of Food Science and Technology, 55: 721-729.

Lee, S.J., Kim, H.K., Kim, Y.S., Kim, E.K., Hwang, J.W., Lim, B.O., Moon, S.H., Jeon, B.T., Jeon, Y.J., Ahn, C.B. \& Park, P.J. 2012. Biological activity from the gelatin hydrolysates of duck skin by-products. Process Biochemistry, 47: 1150-1154.

Liu, R., Xing, L., Fu, Q., Zhou, G. \& Zhang, W. 2016. A Review of Antioxidant Peptides Derived from Meat Muscle and By-Products. Antioxidants, 5(3): 32.

Lorenzo, J.M., Munekata, P.E.S., Gómez, B., Barba, F.J., Mora, L., Pérez-Santaescolástica, C. \& Toldrá, F. 2018. Bioactive peptides as natural antioxidants in food products - A review. Trends in Food Science \& Technology, 79: 136147.

Luna-vital, D.A., Mojica, L. \& Gonz, E. 2014. Biological potential of protein hydrolysates and peptides from common bean (Phaseolus vulgaris L.): A review. Food Research International, 76(1): 39-50.

Mosquera, M., Gimenez, B., Ramos, S., LopezCaballero, M.E., Gomez-Guillen, M. \& Montero, P. 2015. Antioxidant, ace-inhibitory and antimicrobial activities of peptide fractions obtained from dried giant squid tunics. Journal of Aquatic Food Product Technology, 25(3).

Nenadis, N. \& Tsimidou, M.Z. 2018. DPPH (2,2- di (4-tert-octylphenyl)-1-picrylhydrazyl) radical scavenging mixed-mode colorimetric assay(s). Measurement of Antioxidant Activity and Capacity: Recent Trends and Applications, 8: 141-161.

Nik Muhammad, N., Huda, N., Karim, A.A. \& Nafchi, A.M. 2017. Effects of acid type extraction on characterization and sensory profile of duck feet gelatin: towards finding bovine gelatin alternative. Journal of Food Measurement and Characterization, 12: 480-486.

Piotrowicz, I.B.B. \& Mellado, M.M.S. 2015. Antioxidant hydrolysates production from argentine anchovy (Engraulis anchoita) with different enzyme. International Food Research Journal, 22: 3, 1203-1211. 
Razali, A.N., Amin, A.M. \& Sarbon, N.M. 2015. Antioxidant activity and functional properties of fractionated cobia skin gelatin hydrolysate at different molecular weight. International Food Research Journal, 22(2): 651-660.

Salem, R.B.S.B., Bkhairia, I., Abdelhedi, O. \& Nasri, M. 2017. Ocotopus vulgaris Protein Hydrolysates: Characterization, Antioxidant and Functional Properties. Journal of Food Science and Technology, 54: 1442-1454.

Toldra, F., Reig, M., Aristoy, M.C. \& Mora, L. 2017. Generation of bioactive peptides during food processing. Food Chemistry, 267: 395-4040.

Vazquez, A.J., Blanco, M., Massa, A.E, Amado, I.R., Perez-Martin, R.I. 2017. Production of fish protein hydrolysates from Scyliorhinus canicula discards with antihypertensive and antioxidant activities by enzymatic hydrolysis and mathematical optimization using response surface methodology. Marine Drugs, 15: 306.
Wang, D., Zhang, B., Zou, Y., Sun, Z. \& Xu, W. 2018. Optimization of flavourzyme hydrolysis condition for the preparation of antioxidant peptides from duck meat using response surface methodology. Japan Poultry Science Association, 55: 217-223.

Wang, L., Huang, J., Chen, Y., Huang, M. \& Zhou, G. 2015. Identification and characterization of antioxidant peptides from enzymatic hydrolysates of duck meat. Journal of Agriculture and Food Chemistry, 63(13): 3437 3444. 